\title{
PATH ANALYSIS ON SECONDARY SMOKING AND OTHER FACTORS ASSOCIATED WITH THE RISK OF HYPERTENSION IN PREGNANCY: EVIDENCE FROM MAGELANG, CENTRAL JAVA
}

\author{
Erin Rizkiana'), Uki Retno Budihastuti²), Vitri Widyaningsih3) \\ 1)Masters Program in Public Health, Universitas Sebelas Maret \\ ${ }^{2)}$ Department of Obstetrics and Gynecology, Dr. Moewardi Hospital, Surakarta \\ 3)Faculty of Medicine, Universitas Sebelas Maret, Surakarta
}

\begin{abstract}
Background: Gestational hypertension is a condition characterized high blood pressure during pregnancy. It may cause maternal and fetal morbidity and remains a leading source of maternal mortality. The purpose of this study was to examine the association between secondary smoking and other factors with the risk of hypertension in pregnancy.

Subjects and Method: A case control study was carried out at five community health centers (puskesmas) in Magelang, Central Java, from April to May 2019. A sample of 210 pregnant women was selected by simple random sampling. The dependent variable was hypertension. The independent variables were age, parity, nutritional status, history of hypertension in family, history of hypertension before pregnancy, history of hormonal contraceptive, smoke exposure, and antenatal care (ANC). Data on blood pressure was measured by sphygmomanometer. The other variables were measured by questionnaire. The data were analyzed by path analysis.

Results: Gestational hypertension was directly and positively affected by age $(b=1.42$; $95 \% \mathrm{CI}=0.18$ to $2.67 ; \mathrm{p}=0.024)$, nutritional status $(\mathrm{b}=1.68 ; 95 \% \mathrm{CI}=0.42$ to $2.94 ; \mathrm{p}=$ o.009), history of hypertension in family $(b=1.99 ; 95 \% \mathrm{CI}=0.62$ to $3.35 ; \mathrm{p}=0.004)$, history of hypertension before pregnancy $(b=2.17 ; 95 \% \mathrm{CI}=0.77$ to $3.56 ; \mathrm{p}=0.002)$, and smoke exposure $(b=2.12 ; 95 \% \mathrm{CI}=0.70$ to $3.54 ; \mathrm{p}=0.003)$. It was negatively affected by regular ANC visit $(b=-3.42 ; 95 \% \mathrm{CI}=-4.66$ to $-2.18 ; \mathrm{p}<0.001)$.

Conclusion: Gestational hypertension is directly and positively affected by age, nutritional status, history of hypertension in family, history of hypertension before pregnancy, and smoke exposure. It is negatively affected by regular ANC visit.
\end{abstract}

Keywords: hypertension, pregnancy, smoke exposure, path analysis

\section{Correspondence:}

Erin Rizkiana. Masters Program in Public Health, Universitas Sebelas Maret. Jl. Ir. Sutami 36A, Surakarta 57126, Central Java. Email: erinrizkiana777@gmail.com. Mobile: 085729883106. 